\title{
Validation of defining characteristics for the nursing diagnosis of fatigue in oncological patients
}

\author{
Priscila de Oliveira da Silva ${ }^{1}$ \\ Maria Isabel Pinto Coelho Gorini²
}

\begin{abstract}
The objective of this study was to validate the defining characteristics for the nursing diagnosis of Fatigue in adult oncological patients. It is a cross-sectional, descriptive study with a quantitative perspective, and its type is diagnostic content validation. Data collection was carried out in a University Hospital. The sample was made up of 35 expert nurses. The instrument used was subdivided into four parts. The data was analyzed by descriptive statistics. 15 defining characteristics were identified, considered secondary indicators. With an average weighting of less than 0.50 , four defining characteristics were excluded. The defining characteristic Impaired social interaction, added to those described by NANDA-I after review of the literature, was validated with a weighted average of 0.71 . It was concluded that the subjectivity of the defining characteristics and the difficulty nurses have in recognizing them influence the identification of this diagnosis.
\end{abstract}

Descriptors: Validation Studies; Oncologic Nursing; Nursing Diagnosis; Fatigue.

\footnotetext{
${ }^{1}$ RN, MSc, Hospital de Clínicas de Porto Alegre, Brasil.

2 PhD, Adjunct Professor, Universidade Federal do Rio Grande do Sul, Brazil.
} 


\section{Validação das características definidoras do diagnóstico de Enfermagem: fadiga no paciente oncológico}

O objetivo deste estudo foi validar as características definidoras do diagnóstico de Enfermagem, fadiga, em pacientes adultos oncológicos. Trata-se de estudo transversal e descritivo, em perspectiva quantitativa, do tipo validação de conteúdo diagnóstico. A coleta de dados foi realizada em um hospital universitário. Fizeram parte da amostra 35 enfermeiros peritos. Utilizou-se um instrumento subdividido em quatro partes. Os dados foram analisados por estatística descritiva. Identificaram-se 15 características definidoras, consideradas indicadores secundários. Com média ponderada inferior a 0,50, foram excluídas quatro características definidoras. A característica definidora Interação Social Prejudicada, acrescentada às descritas pela NANDA-I, após revisão da literatura, foi validada com média ponderada de 0,71 . Concluiuse que a subjetividade das características definidoras do diagnóstico de Enfermagem, fadiga, e a dificuldade dos enfermeiros em reconhecê-las, influenciam na identificação desse diagnóstico.

Descritores: Estudos de Validação; Enfermagem Oncológica; Diagnóstico de Enfermagem; Fadiga.

\section{Validación de las características definidoras del diagnóstico de enfermería Fatiga, en pacientes oncológicos}

Este estudio tiene como objetivo validar las características definidoras del diagnóstico de enfermería fatiga en pacientes adultos oncológicos. Se trata de un estudio transversal y descriptivo, en una perspectiva cuantitativa, del tipo validación de contenido diagnóstico. La recolección de datos fue realizada en un Hospital Universitario. Compusieron la muestra 35 enfermeros peritos. Para la recolección de datos, se utilizó un instrumento subdividido en cuatro partes. Los datos fueron analizados por estadística descriptiva. Se añadió las características definidoras Interacción Social Perjudicada. No se encontró principales indicadores. Fueron identificados 15 características definidoras como indicadores secundarios. Con media ponderada inferior a 0.50 , se excluyeron cuatro CD's. La característica definidora Interacción Social Perjudicada, añadido a los descritos por la NANDA-I después de la revisión de la literatura, fue validada con media ponderada de 0.71 . Se concluyó que la subjetividad de las características definidoras del diagnóstico de enfermería fatiga y la dificultad de los profesionales en reconocerlos influenció en la identificación de este diagnóstico.

Descriptores: Estudios de Validación; Enfermería Oncológica; Diagnóstico de Enfermería; Fadiga.

\section{Introduction}

In the care of oncological patients, the establishment of accurate Nursing Diagnoses (ND) can contribute to improvement in the patient's quality of life. Nursing actions grounded in NDs are directed at real problems experienced by this population.

Many NDs have considered the problems experienced by oncological patients during the different phases of their illness and types of treatment. One ND which reflects a symptom caused by cancer and/or oncological treatment, however, is fatigue. If not diagnosed appropriately fatigue can debilitate the oncological patient, interfere with treatment and impair quality of life.

Fatigue affects from $70 \%$ to $100 \%$ of patients who receive chemotherapy drugs, radiotherapy, or transplant of bone marrow or peripheral stem cells and biological response modifiers ${ }^{(1)}$. It is the most prevalent and longestlasting symptom in terminally-ill patients, being reported by about $80 \%$ of patients during the course of the illness, with the prevalence varying between $75 \%$ and $99 \%$ in patients with advanced disease receiving palliative care, becoming more intense as death approaches.(2).

Fatigue's complexity is considered in the ND, as it includes a group of Defining Characteristics (DCs) which must be present for the diagnosis to be established. The ND 'Fatigue' is included in the diagnostic terminology proposed by Nanda International (NANDA-I)(3). The inclusion of this ND happened in NANDA's Taxonomy I in 1988 and, currently, the ND Fatigue is presented with 
the following definition "an overwhelming sustained sense of exhaustion and decreased capacity for physical and mental work at usual level"(3). This definition has shown itself to be suited to the fatigue experienced by oncological patients, principally those in palliative care situations. This definition highlights the dimension of temporality present in the concept, through the term 'sustained', which denotes the chronic nature of this symptom(2).

Some studies have identified the ND of fatigue in the sample researched. Among these, one carried out in the chemotherapy outpatients department of a University Hospital stands out. It aimed to establish the Nursing Diagnoses prevalent in eleven patients with colorectal cancer. 23 NDs were identified based on basic human needs which were altered in this population, and the existence of the ND of Fatigue was established in three patients ${ }^{(4)}$.

Contrary to these results, a recent study undertaken in a University Hospital in South Brazil has shown that the ND of Fatigue was present in $0.9 \%$ of a sample of 109 patients with cancer. However, the DCs of the ND of Fatigue were present in $15.9 \%$ of the medical records, described in the nurses' daily routines. The authors remained in doubt as to whether the DCs fitted the ND of Fatigue, as the nurses, despite identifying the DCs, did not establish the ND of Fatigue(5).

It may be observed in a bibliographic review study that similarities were found between the DCs of the ND of Fatigue as found in NANDA-I and the description of fatigue in the Oncology Nursing literature. The DCs which were similar were: tired, lethargic or listless, an increase in physical complaints, disinterest in surroundings, introspection, decreased performance, verbalization of an unremitting and overwhelming lack of energy, increase in rest requirements; inability to restore energy even after sleep, lack of energy or inability to maintain usual levels of physical activity or routines and compromised concentration. No correspondence was found, however, with the following defining characteristics from NANDA: perceived need for additional energy to accomplish routine tasks, drowsy, compromised libido and feelings of guilt for not keeping up with responsibilities ${ }^{(6)}$.

It is believed that the establishing of the ND of Fatigue in oncological patients may favor educational activities for the management of fatigue, and guide measures for its prevention. This study also proposes to highlight this diagnosis, clarifying the meaning of each DC.

Thus, the objective of this study was to validate the DCs of the ND of fatigue in oncological patients.

\section{Methods}

It is a cross-sectional descriptive study, in a quantitative perspective, of the Content Validation
Diagnostics (CVD) type proposed by Fehring(7), which is based on obtaining the opinions of expert nurses concerning the degree to which specified characteristics are indicative of a specified diagnosis. In this validation model, the author suggests that a literature review should be done so as to provide theoretical support for the defining characteristics and, further, emphasizes that during this process there is the possibility that the defining characteristics might be added to the list established by NANDA-I(7).

This research was carried out at the Clinical Hospital of Porto Alegre (CHPA) in the State of Rio Grande do Sul, Brazil. This institution has specific departments for the treatment of oncological patients, such as the Hematopoietic Stem Cell Transplant Unit, Chemotherapy and Radiotherapy, apart from the Clinical and Surgical Units, which also receive oncological patients at different stages of the illness.

In relation to the population, of the 123 nurses who worked in the units where data collection was undertaken, 35 were selected as experts.

The criteria for the selection of the experts were adapted from the model proposed by Fehring(7). To be considered an expert, the nurses had to have at least five points in the criteria described in Figure 1. These criteria were developed especially for this study, so as to include non-management/-administrative nurses who provide care to oncological patients and who had experience with the terminology of NANDA-I.

\begin{tabular}{|lc|}
\hline Criteria & Scoring \\
\hline Have PhD or Master's. & 3 \\
$\begin{array}{l}\text { Have title of Specialist in Oncology Nursing, from the } \\
\text { Brazilian Society of Oncology Nursing (BSNO). } \\
\begin{array}{l}\text { Specialization or residency program in Oncology } \\
\text { Nursing. }\end{array}\end{array}$ & 3 \\
$\begin{array}{l}\text { Use NANDA-I diagnostic terminology in clinical } \\
\text { practice. }\end{array}$ & 3 \\
$\begin{array}{l}\text { Minimum of one year's clinical practice with } \\
\text { oncological patients. }\end{array}$ & 2 \\
$\begin{array}{l}\text { Research or articles published on NCS, ND or } \\
\text { oncology. } \\
\text { Abstracts published on NCS, ND or oncology } \\
\text { Participation in courses or congresses referent to } \\
\text { NCS, ND or oncology, minimum of } 4 \text { hours. }\end{array}$ & 2 \\
\hline
\end{tabular}

Figure 1 - Criteria used for selection of expert nurses in this study. Porto Alegre, Rio Grande do Sul, Brazil, 2010

It's important to emphasize that, to participate in the study, the nurses accepted to respond to the data collection instrument. The handing-back of the instrument took place at a pre-arranged time, which varied from 24 hours later to two weeks. 
Experts who failed to return the filled-out questionnaire during the data collection period, or who returned it only partly-filled out, were excluded.

The participants were invited by the researcher to participate in the study during periodical visits to the units. After acceptance, they received an instrument for data collection and agreed a date for returning it, according to each nurse's availability for responding to the questionnaire.

Data related to the subjects was analyzed through descriptive statistics, using frequencies and averages. For analysis of the DCs, the researchers calculated a weighted average of the grades which the nurses had given to each defining characteristic, in line with the methodology suggested by Fehring(7), in which one considers the following values, referent to the Likert Scale: $1=0 ; 2=0.25 ; 3=0.50 ; 4=0.75 ; 5=1$. This stage is part of the first of five steps suggested by Fehring(7) for analysis of the data.

This being so, the content validation of 19 DCs described by NANDA-I, corresponding to the ND of Fatigue, was carried out. To these, one defining characteristic identified in the literature review was added: Impaired Social Interaction.

The definition given for this characteristic is the following: compromising of the relations between members of a group or between groups. It is characterized by the refusal of invitations which lead the patient to interact with other individuals, and by inability to tolerate the stimulation associated with social interactions, even with members of the family or friends ${ }^{(8-9)}$.

The second step, which is considered optional, uses the Delphi technique, with repeated rounds of questionnaires, so as to obtain a consensus of a group of expert nurses on the subject of DCs of the ND of Fatigue studied (this step was not used in this study).

The third step involves calculating the weighted averages of the grades given to each of the DCs. In the fourth step, DCs with weighted averages inferior to 0.50 are discarded. The excluded DCs were: disinterest in surroundings, lethargic, compromised concentration and listless.

In the fifth step, the DCs with averages of between 0.79 and 0.50 are considered as secondary indicators; these are characteristics which offer secondary evidence supporting the diagnosis(10). 15 DCs were identified as secondary indicators.

Finally, those with a weighted average equal or superior to 0.80 are considered principal indicators, that is, characteristics which must be present to validate the diagnosis, affirming that the diagnosis actually exists ${ }^{(10)}$. Primary indicators were not identified.
Below, the total CVD score will be obtained through summing the individual scores and dividing them by the total number of DCs for the diagnosis, excluding those with a weighted average of $\leq 0.50^{(7)}$.

All the ethical and legal aspects of research on human beings were considered, in line with Resolution n0196/96 of the Ministry of Health's National Health Council(11), being approved by the Research Commission (COMPESQ) of the Rio Grande do Sul Federal University Nursing School (UFRGS) and by the Post-Graduate and Research Group of the Porto Alegre Clinical Hospital (GPPG/HCPA), under $n^{\circ} 100026$. The participants who agreed to participate in the study signed the Terms of Free and Informed Consent.

\section{Results}

35 expert nurses took part in the study, all being female and caring for oncological patients in the Clinical and Surgical Inpatient Units, the Chemotherapy and Radiotherapy Outpatient Units, and the Hemopoietic Stem Cell Transplant Unit, in the three work shifts (morning, afternoon and night). Table 1 describes the sample profile.

Table 1 - Description of the sample profile, relating to academic qualifications, scientific production and clinical experience in years, $(n=35)$

\begin{tabular}{|c|c|c|}
\hline Variables & $f$ & $\%$ \\
\hline \multicolumn{3}{|l|}{ Academic qualification } \\
\hline Degree & 9 & 25.7 \\
\hline $\begin{array}{l}\text { Specialist in Oncology Nursing and Specialist } \\
\text { recognized by BSNO }\end{array}$ & 8 & 22.8 \\
\hline Specialist in other areas & 12 & 34.3 \\
\hline Master's degree & 6 & 17.1 \\
\hline \multicolumn{3}{|l|}{ Scientific production } \\
\hline $\begin{array}{l}\text { Research, articles published on NCS, ND or } \\
\text { oncology }\end{array}$ & 4 & 11.4 \\
\hline Abstracts published on NCS, ND or oncology & 3 & 8.6 \\
\hline Participation in courses on NCS & 21 & 60 \\
\hline \multicolumn{3}{|l|}{ Clinical experience in years } \\
\hline $1-5$ & 9 & 25.7 \\
\hline $6-10$ & 6 & 17.1 \\
\hline $11-15$ & 6 & 17.1 \\
\hline $16-20$ & 4 & 11.4 \\
\hline $21-25$ & 8 & 22.8 \\
\hline $26-30$ & 2 & 5.7 \\
\hline
\end{tabular}

In relation to the scoring, all the experts obtained a minimum of five points, according to the criteria already presented for their selection. It can be observed that the total score varied between 5 and 14 points, with an average of 7.3 points and a standard deviation of 2.5 among the 35 experts in this study. 
As far as secondary indicators are concerned, 15 defining characteristics (weighted average $<0.80$ and $>0.50$ ) were identified as such, as shown in Table 2 .

Table 2 - Weighted averages of the defining characteristics of the ND for Fatigue, identified as secondary indicators according to the judgment of the experts.

\begin{tabular}{lc}
\hline \multicolumn{1}{c}{ Defining Characteristics } & Weighted Average \\
\hline Inability to maintain usual level of physical activity & 0.79 \\
Increase in physical complaints & 0.74 \\
Lack of energy & 0.74 \\
Inability to restore energy even after sleep & 0.74 \\
Inability to maintain usual routines & 0.73 \\
Introspection & 0.73 \\
Decreased performance & 0.72 \\
Perceived need for additional energy to accomplish & 0.70 \\
routine tasks & \\
Tired & 0.69 \\
Compromised libido & 0.69 \\
Verbalization of an unremitting lack of energy & 0.66 \\
Increase in rest requirements & 0.65 \\
Feelings of guilt for not keeping up with & 0.63 \\
responsibilities & \\
Drowsy & 0.61 \\
Verbalization of an overwhelming lack of energy & 0.54 \\
\hline
\end{tabular}

The four characteristics which were excluded are described in Table 3.

Table 3 - Weighted average of the defining characteristics of the ND for Fatigue which were excluded, according to the judgment of the experts

\begin{tabular}{lc}
\hline \multicolumn{1}{c}{ Defining Characteristics } & Weighted Average \\
\hline Disinterest in surroundings & 0.49 \\
Lethargic & 0.49 \\
Compromised concentration & 0.48 \\
Listless & 0.42 \\
\hline
\end{tabular}

The defining characteristic Impaired Social Interaction, which was suggested following a literature review, was validated as a secondary indicator (weighted average 0.71 ).

\section{Discussion}

The size of the sample seems not to have influenced the results, as the opinion of the experts was uniform. Although the majority of the validation studies use the model proposed by Fehring, there is no defined consensus about the criteria for selecting experts ${ }^{(12)}$. It is important that these criteria should be appropriate to the sample studied, which is why they were adapted in this study.
All the experts confirmed that they had experience with the NANDA-I diagnostic terminology and a minimum of one year's clinical experience of working with oncological patients, as per the requirements previously established for being an expert.

The experts with Master's degrees formed $17.1 \%$ of the sample. Two of the experts were studying for Master's degrees. $22.8 \%$ of the experts had undertaken the Oncology Nursing course. In the current scenario it may be observed that the activity of the nurse is growing, considering the improving of oncological treatment and the new proposals for treatment.

Four experts - that is, $11.4 \%$ - were identified as having the title of Specialist in Oncology Nursing from the BSNO. The BSNO was founded in 1888 and describes itself as a not-for-profit organization. The title, bestowed by the BSNO, is acquired by title examination and a written exam(13). It should be emphasized that these experts had taken the Oncology Nursing specialization course. However, the majority of the experts (34.3\%) described themselves as specialist in other areas, such as Public Health, Health Service Auditing, Intensive Therapy, and Health Service Administration. This information shows that these professionals' specialized knowledge contributed to the validation of the DCs and ND for Fatigue, as the oncological patient ends up circulating through the different sectors with these professionals.

It may also be observed that the search for knowledge makes the specializations an alternative for professional improvement in a highly competitive market. Apart from that, it is necessary for nurses who are active in health services to seek scientific knowledge which supports caregiving practice ${ }^{(14)}$.

Concerning the DCs, no principal indicators for this diagnosis (weighted average $\geq 0.80$ ) were identified in the opinions of the experts. These indicators would be evidence that the ND of Fatigue is appropriate. This result may be attributed to the subjectivity which permeates the defining characteristics of this diagnosis(6), that is, most are based on the discourse of the patient herself. This fact emphasizes the importance of a complete evaluation, including therapeutic listening, making it possible for people to express what they are feeling. An overload of tasks very often means that the nurse cannot give adequate attention to the patients - and because of this, some characteristics which are subjective are forgotten or unmentioned.

Apart from this, the cut-off point (0.80) may not be appropriate for the evaluation of the principal indicators, being considered high for their validation. It is necessary to undertake studies which render the 
cut-off point recommended by Fehring appropriate to the reality in Brazil. Another fact which may have contributed to this result is related to the academic qualification of the experts who did the validation. Although all the experts reported having experience with oncological patients, only $22.8 \%$ of the experts were specialists in oncology nursing. It was decided to include nurses with other specialities to show that these, even with their specific knowledge being from other areas, were experts, due to their clinical experience with oncological patients, as a result of their providing daily hands-on care to these patients in all phases of the illness.

Of the DCs which were identified as secondary indicators, eight had a weighted average between 0.70 and 0.79 . The DC with the strongest indicator is Inability to maintain usual level of physical activity (0.79), which showed similarities with the DC Inability to maintain usual routines (0.73). Both represent the difficulty people have in carrying out activities of daily life: activities such as walking, taking exercise, cleaning the house, cooking and even eating can become highly challenging for patients with fatigue ${ }^{(15)}$, directly influencing their quality of life. The DC Increase in physical complaints is frequently identified in patients with fatigue(16-17), but was not validated in healthy women living in a city in the Mid-West of the United States along with the DC Feelings of guilt for not keeping up with responsibilities ${ }^{(18)}$, differently from the results of this research, which validate these DCs with the respective scores of 0.74 and 0.63 .

Tired (0.69) and Lack of energy (0.74) are closelylinked defining characteristics. Both are frequently reported by patients with fatigue, being considered, as a result, synonymous. Fatigue related to cancer is described, by the patients, as extreme tiredness ${ }^{(19)}$.

The DC Decreased performance (0.72) is a subjective symptom related to the motivation or cognitive impairment which fatigue can cause(20). The DC Perceived need for additional energy to accomplish routine tasks (0.70) sheds light on the lack of energy of those who feel it, once they find themselves unable to continue their tasks which they had previously done.

The alterations in sleep patterns of people stricken by neoplasias with fatigue are common. Patients with fatigue report feeling tired even after a night's sleep ${ }^{(21)}$. The DC Inability to restore energy even after sleep (0.74) and the DC Drowsy (0.61) clearly define this situation, making it an important element in the detection of fatigue.

The DCs Verbalization of $n$ unremitting lack of energy (0.66) and Verbalization of an overwhelming lack of energy (0.54) bring up the question of subjectivity, as they are DCs based in the patients' reports. However, even with the verbalization of something as characteristic as lack of energy, fatigue is neither identified or evaluated appropriately by health care professionals(22).

The DCs Compromised Concentration (0.48), Listless (0.42), Disinterest in surroundings (0.49) and Lethargic (0.49) were excluded. Among these, in some studies ${ }^{(15,19,21)}$, the DC Compromised concentration is mentioned as being frequent in patients with fatigue, but due to the fact of the patient being in hospital, this characteristic is not identified frequently, in the opinion of the experts.

The suggested DC Impaired Social Interaction obtained a weighted average among the experts of 0.71 , being selected as a secondary indicator of the ND of fatigue in the oncological patient. Some studies undertaken with patients in outpatient treatment have indicated the difficulty that patients with fatigue have in interacting socially, for example going to the mall, going to restaurants, playing with their children, staying with friends or just enjoying life at that moment(21,23).

The total CVD found was of 0.69. Of the DCs of the ND of Fatigue proposed by NANDA-I, along with the DC indicated in this study, 55\% (11 DC's) obtained a score above the total CVD, which indicates that the majority of the DCs are relevant for diagnosing the ND of Fatigue in the oncological patient ${ }^{(24)}$.

\section{Conclusions}

Validating the ND of Fatigue in the oncological population was chosen because Fatigue is an adverse event which has affected these patients frequently, as well as being debilitating, influencing the oncological patient's quality of life. Further, the lack of Brazilian studies on this subject may be related to the difficulty of identifying fatigue. This being so, the content validation of the 19 defining characteristics belonging to NANDA-I, plus one characteristic identified in the literature review, was carried out.

In the experts' opinion, no principal indicators were identified, and 15 DCs were identified as secondary indicators. The total CVD score was 0.69 , which shows that more than half of the defining characteristics of the ND of Fatigue obtained a score equal to or greater than this, demonstrating that the majority of the DCs of the ND of Fatigue are related to the oncological patient and are relevant to its identification.

For continuity of this study, it is suggested that clinical validation of this diagnosis be carried out in oncological patients who have the same neoplasia and the same oncological treatment, as was also suggested by the 
experts, as - according to them - the fatigue experienced by the patients can vary with the stage of treatment and, due to this, a more specific study is needed.

\section{Referencias}

1. Bonassa EMA. Enfermagem em terapêutica oncológica. 3.ed. São Paulo: Atheneu; 2005.

2. Mota DDCF, Pimenta CAM. Controle da Fadiga. In: Mota DDCF, Pimenta CAM, Cruz DALM. Dor e cuidados paliativos: enfermagem, medicina e psicologia. Barueri: Manole; 2006. p. 193-206.

3. NANDA Internacional. Diagnósticos de enfermagem da NANDA: definições e classificações, 2009-2011. Porto Alegre: Artmed; 2010.

4. Silva PO, Gorini MIPC. Nursing diagnosis of patients with colorectal neoplasia undergoing chemotherapy treatment - a qualitative research.Online Braz J Nurs. [periódico na Internet]. 2008; [acesso 18 dez 2009]. 7(2). Disponível em: http://www.objnursing.uff.br/index.php/nursing/ article/view/j.1676-4285.2008.1521/385.

5. Gorini MIPC, Silva PO, Chaves PL, Ercole JP, Cardoso BC. Registro do diagnóstico de enfermagem fadiga em prontuários de pacientes oncológicos. Acta Paul Enferm. Jun2010;23(3):354-8.

6. Menezes MFB, Camargo TC. A fadiga relacionada ao câncer como temática na enfermagem oncológica. Rev. Latino-Am. Enfermagem. mai-jun 2006;14(3):442-7.

7. Fehring RJ. Methods to validate nursing diagnoses. Heart \& Lung. 1987 Nov;16(6):625-9.

8. Houaiss A, Villar MS, Franco FMM. Dicionário Houaiss da língua portuguesa. Rio de Janeiro: Objetiva; 2009.

9. Olson K, Turner AR, Courneya KS, Field C, Man G, Cree $M$, Hanson J. Possible links between behavioral and physiological indexes of tiredness, fatigue, and exhaustion in advanced cancer. SupportCareCancer. 2008; 16:241-9.

10. Galdeano LE, Rossi LA, Pelegrino FM. Validação de conteúdo do diagnostico de enfermagem conhecimento deficiente. Acta Paul Enferm. 2008;21(4):549-55.

11. Ministério da Saúde (BR). Conselho Nacional de Saúde. Resolução 196/96. Diretrizes e Normas Regulamentadoras de Pesquisas Envolvendo Seres Humanos. 1996. [acesso 20 nov 2008]. Disponível em:http://www.ufrgs.br/ bioetica/res19696.htm.

12. Carvalho EC, Mello AS, Napoleão AA, Bachion MM, Dalri MCB, Canini SRMS. Validação de diagnóstico de enfermagem: reflexão sobre dificuldades enfrentadas por pesquisadores. RevEletrEnferm. [periódico na Internet]. 2008;10(1):235-40. Disponível em: http://www.fen.ufg. br/revista/v10/n1/v10n1a22.htm.
13. Sociedade Brasileira de Enfermagem Oncológica (SBEO). Histórico. [acesso $16 \mathrm{fev}$ 2011]. Disponível em: http:// www.sbeonet.com.br/portal/index.php?option=com_conte nt\&view $=$ article\&id $=109 \&$ Itemid $=105$.

14. Oliveira NAL, Thofehrn MB, Cecagno D, Siqueira $\mathrm{HCH}$, Porto AR. Especializaçao em projetos assistenciais de enfermagem: contribuições na prática profissional dos egressos. Texto Contexto Enferm. dez 2009;18(4): 697-704.

15. Curt GA. The impact of fatigue on patients with cancer: Overview of Fatigue 1 and 2. Oncologist. 2000; 5Suppl 2:9-12.

16. Ream E, Richardson A. Fatigue in patients with cancer and chronic obstructive airways disease: a phenomenological enquiry. Int J Nurs Stud. 1997;34(1):44-53.

17. Potter J. Fatigue experience in advanced cancer: a phenomenological approach. Int J Palliative Nurs. 2004;10(1):15-23.

18. Fu M, LeMone P, McDaniel RW, Bausler C. A Multivariate Validation of the Defining Characteristcs of Fatigue. NursDiagn. 2001 Jan-Mar;12(1):15-27.

19. Wu HS, McSweeney M. Cancer-related fatigue: "It's so much more than just being tired". Eur J OncolNurs. 2007 Apr;11(2):117-25.

20. Morrow GR. Cancer-related fatigue: causes, consequences, and management. Oncologist. 2007;12Suppl 1:1-3.

21. Goedendorp MM, Gielissen MFM, Verhagen $\mathrm{CAH}$, Peters MEJW, Bleijenberg G. Severe fatigue and related factors in cancer patients before the initiation of treatment. $\mathrm{Br} J$ Cancer. 2008;99(9):1408-14.

22. Given B. Cancer-related fatigue: A brief overview of current nursing perspectives and experiences. Clin J OncolNurs. 2008;12Suppl 5:7-9.

23. Curt GA, Breitbart W, Cella D, Groopman JE, Horning SJ, Itri LM, et al. Impact of Cancer-Related Fatigue on the Lives of Patients: New Findings From the Fatigue Coalition. Oncologist. 2000;5:353-60.

24. Capellari C, Almeida MA. Nursing diagnosis Ineffective Protection: content validation in patients under hemodialysis. RevGauchaEnferm. 2008 Sept;29(3):415-22. 